\title{
Haití desde las entrañas de un reportero gráfico
}

Fecha de recepción: 23/03/2010 - Aprobación:05/04/2010

Martha Isabel Hernández Aguirre

\section{Resumen}

Simone Bruno, es periodista y reportero gráfico italiano, quien cubrió la tragedia de Haití como medio independiente, durante diez días en Puerto Príncipe. Simone es un profesional con un alto sentido social y humanitario. Vive en Bogotá hace seis años y es candidato al Magíster en Estudios Latinoamericanos de la Pontificia Universidad Javeriana. Las fotografías y sus denuncias sobre la verdadera situación han sido registradas en diferentes medios de comunicación internacionales. Habló para Poliantea sobre su impresión de la tragedia, su pensamiento antes de tomar las fotografías, el conflicto humanitario, geopolítico, cultural y social en ese país del Caribe.

\section{Palabras clave}

Comunicación, Haití, terremoto, rescate, fotografía, periodismo.

\begin{abstract}
Simone Bruno, is an italian journalist and photojournalist, who covered the tragedy of Haiti as independent media for ten days in Port au Prince. Simone is a professional with a high social and humanitarian sense. He has lived in Bogota for six years and is a master's candidate in Latin American Studies at the Pontificia Universidad Javeriana. Photographs and reports of Simone about the true situation in Haiti have been recorded in various international media. Simone talked about his impressions of the tragedy in Haiti, his thoughts before taking the photographs and the humanitarian, geopolitical, cultural and social conflicts in Haiti.
\end{abstract}

\section{Keywords}

Comunication, Haiti, earthquake, rescue, photography journalism.

\section{Introducción}

Simone Bruno expresó desde las entrañas de un reportero gráfico, su experiencia sobre diversos aspectos que aún se desconocen de la tragedia de Haití.

Las fotografías y las denuncias de Simone sobre la situación en Haití han sido registradas en diferentes medios de comunicación internacionales.
De Colombia viajé a Santo Domingo, con un amigo de CNN que iba también con la caravana de este medio para Haití. Alquilamos un carro para ir a Puerto Príncipe, el viaje fue muy largo. Al entrar a Haití se atraviesa una frontera que realmente separa dos mundos completamente diferentes, hasta la vegetación cambia. Creo que la explotación de la vegetación allí ha sido muy fuerte, el paisaje es completamente distinto, solo hay un larga carretera hasta llegar a un trancón 
Haití es un país que ha sido invadido, conquistado, y después ayudado con la misma violencia. increíble, todos los carros estaban parados, la gente caminaba y caminaba sin rumbo. La gente todo el tiempo está caminando y nadie sabe para dónde van. No había controles a la entrada, todo el mundo pasaba a Haití, había redes abiertas, nadie nos pidió el pasaporte.

Con estas palabras se inicia esta historia del periodista y reportero gráfico Simone Bruno en Puerto Príncipe.

\section{¿Cuál fue su primera impresión de Haití?}

Simón Bruno: Al llegar a Puerto Príncipe, al tercer día de ocurrido el terremoto, lo que más me impactó fue cuando el primer día salimos y dimos un primer recorrido. Allí, las imágenes que había en mi mente de lo que iba a ver y lo que ya había visto en los medios, se chocaron con la cruda realidad y fue bastante duro. Fue muy impactante ver que nadie estaba escavando, nadie buscaba a nadie, era evidente la falta de ayuda internacional para los damnificados, empezaba a oler a cadáver y al día siguiente el olor era más fuerte, luego iba en aumento hasta volverse permanente y esto se queda grabado en la memoria.

\section{¿Cuál es su visión política de Haití?}

SB: Haití es un país que ha sido invadido, conquistado, y después ayudado con la misma violencia. La ayuda de la Misión Estabilizadora de las Naciones Unidas en Haití (Minustah) brasilera, es un tipo de asistencialismo, que de pronto no colabora con el desarrollo del país. Varios cooperan-

\section{Reseña de autor}

Martha Isabel Hernández Aguirre

(Politécnico Grancolombiano)

martachester@gmail.com

Es Magister en Estudios Políticos de la Pontificia Universidad Javeriana, Especialista en Televisión y Comunicadora Social y Periodista. Es docente investigadora de la Facultad de Mercadeo, Comunicación y Artes del Politécnico Grancolombiano. tes italianos y de otros países me confirmaron que allí hay una cultura muy particular, muy diferente al resto de América Latina. Había cooperantes con diversos proyectos como para el agua potable que, por ejemplo, en Bolivia les explicaban y la gente hacía las cosas solos, pero aquí no. Por el contrario, en Haití tocaba contratar a la gente, la cultura se ha vuelto muy individualista. Intenté averiguar el por qué, y la respuesta fue que siendo un país que ha vivido bajo tanta violencia, ha tenido mucha cercanía con la muerte en la cotidianidad, que la hace verla como una cosa normal.

Cuando en Haití, unos a otros se contaban sobre sus familiares muertos, había unas expresiones casi de sonrisa y no había una expresión de luto y de duelo, que uno esperaría en una situación como esta. La cotidianidad con la muerte casi que se vuelve como una parte normal del día tras día. Hay un problema de asimilación de la violencia, que no se expresa con un duelo normal, pero que evidentemente después encuentra una forma de expresión reflejada en la individualización y la violencia que ha vivido el país.

\section{¿Cuál es el actual conflicto político y humanitario en Haiti?}

SB: Estados Unidos se está aprovechando de la tragedia para golpear a Suramérica y, en especial, a Brasil, país que estaba guiando la Minustah, que es la única misión de la ONU en el mundo guiada por un país latinoamericano. Lo que hizo Estados Unidos fue intervenir con 10.000 militares, 2.200 marines y tomar el control de la isla, intentando desplazar a los brasileños. Allá hay un juego geopolítico, pues Haití está entre Cuba y Venezuela, y tener 10.000 hombres 
armados en Puerto Príncipe, porta aviones y helicópteros, es evidentemente una estrategia geopolítica que nada tiene que ver con la ayuda a la isla.

\section{¿Qué lo motivó a cubrir este desastre?}

SB: La motivación está en la profesión que uno hace. El periodista quiere estar en el lugar de los hechos y en ese momento era la noticia más importante, y ser testigo de procesos que me interesan y me gustan, como lo fue el cubrimiento de la minga indígena el año pasado. En Haití uno intenta ayudar desde la profesión y el derecho que tienen las personas a la información.

\section{¿Cómo visualizó las diferencias sociales en Haití?}

SB: Allí lo más grave era la tragedia de las diferencias sociales. Hay dos cosas, el barrio de los ricos está intacto, allí no ha pasado nada, ya que son construcciones muy sólidas y de buena calidad; mientras que por el contrario, el resto de edificios, eran trampas mortales, como nos contaron los mismos ingenieros y los socorristas colombianos, italianos y mexicanos.

Las estructuras de los edificios eran muy pesadas, no tenían columnas de concreto, se utiliza arena marina, que es mucho más pesada que la de río y que retiene mayor humedad, sin suficientes columnas en concreto y acero para sostenerlas. Por tanto, cuando ocurrió el terremoto las columnas se despegaron del piso y del techo y se salieron, así que todos los pisos se cayeron unos sobre los otros, y la gente no tuvo tiempo ni siquiera para intentar salir, se murieron todos aplastados.

Otra gran diferencia social fue el hecho que las Naciones Unidas, decidió ayudar solo en los barrios donde estaban los inter- nacionales, allá hasta de noche se trabajaba con excavadoras, equipo de rescatistas todo el tiempo; por el contrario, en el centro de Puerto Príncipe, ciudad que es prácticamente un barrio de clase media baja, nunca vi tan siquiera una excavadora. Esta es una terrible decisión que tomó la ONU de salvar y de dar una prioridad a su gente, a los extranjeros y dejar morir a los haitianos que estaban atrapados en los escombros. Esto lo contaron muchos rescatistas internacionales, quienes nos decían: "No nos permitieron salvar a la gente, me acuerdo del ingeniero Óscar, colombiano, luego de que ellos mismos rescataron a la señora del Hotel Montana, yo creía que los iba a encontrar felices, pero no fue así”.

Óscar decía: "Deberíamos hablar de cómo se están manejando las ayudas y los rescates, cuando llegamos de la base logística, a nosotros nos encerraron en el hotel y al venir de nuevo a la base, vimos miles de personas pidiendo ayudas y no los pudimos socorrer porque no nos lo permitían". Es decir, la decisión de concentrar todas las ayudas en una sola parte de la ciudad fue como una condena a muerte para el resto.

Nos contaba que lo que siempre se hace en estos casos de acuerdo con su experiencia, es que los países se distribuyen las distintas zonas de la ciudad, y con la gente misma se organizan y empiezan a excavar. En Haití no fue así, vi en el Hotel Montana, cuatro grupos de rescate comiendo y sin hacer nada, porque allí había exceso de ayudas.

\section{¿Por qué las donaciones en especie de todos los países no se distribuían?}

SB: Esa era la misma impresión que uno tenía allá, era muy evidente que las ayudas
Allí lo más grave era la tragedia de las diferencias sociales. Hay dos cosas, el barrio de los ricos está intacto, alli no ha pasado nada, ya que son construcciones muy sólidas y de buena calidad; mientras que por el contrario, el resto de edificios, eran trampas mortales, como nos contaron los mismos ingenieros $y$ los socorristas colombianos, italianosy mexicanos. 
humanitarias no llegaban a la gente. Hablé con los encargados de su distribución, del agua y de la comida, pero ellos estaban organizando las cosas de forma muy burocrática, tomaban imágenes satelitales, para ver dónde había más concentración de gente, e iban a tres de estos lugares cada día a entregar la comida. Esto no era suficiente. Comprendo que había la necesidad de evitar los problemas de seguridad pública y estudiar bien la situación para evitar hechos de desorden público. Además había una campaña de algunos medios en los cuales parecía que los haitianos eran monstruos, que más bien antes de ayudarlos había que defenderse de ellos.

Llegaron los gringos y empezaron a distribuir las ayudas, hubo un problema diplomático, entre la ONU y Estados Unidos, la solución que encontraron fue buena para todos, pero no para los haitianos. Se decidió que Estados Unidos, entregaría ayuda humanitaria a los pueblos alrededor de Puerto Príncipe, y esto le permitió llevar en cada helicóptero dos periodistas. Entonces, en el ámbito internacional los gringos tuvieron mucho cubrimiento en el sentido de que estaban ayudando a los haitianos $y$, por otra parte, la ONU decía que ellos eran los que estaban organizando las cosas, pero después no pasó nada y la ayuda tardó mucho más en llegar.

Después del terremoto, de los atrasos, de la falta de ayuda, de la ausencia de rescate, a pesar de todo este caos, de todo lo que sucedía allí, los haitianos eran personas amables, sonrientes, gentiles, me sentía seguro. Siempre iba por las calles con $\mathrm{mi}$ cámara colgada al cuello, y nunca me pasó nada, por eso me molestaba mucho cuando se presentaban las imágenes de saqueos y de violencia. Pero estamos hablando de Haití, no de París y de seres humanos sin nada, con más de diez días sin comer y, con el agravante, de que antes del terremoto ya tenían sus problemas. Pero primero se reactivó mucho el comercio informal que las ayudas humanitarias, en los campamentos de los damnificados se podía comprar Coca-Cola y cerveza, mientras que el agua de la ONU, donada por todos los países, aún no llegaba.

\section{¿Cuánto tiempo durará la recuperación de Haití?}

SB: Eso es imposible decirlo, porque intervienen muchos factores, puede ser que necesite unos diez años, si la ayuda es para hacerlo de verdad, pero si es como la que están recibiendo ahora, una ocupación militar, Haití no se va a recuperar nunca. Hay que trabajar mucho en que la gente se organice, se active y hagan ellos mismos las cosas, sino se vuelve la típica ayuda de Europa a África y cuando esta se acaba, se acaba todo.

\section{¿Por qué cree que los haitianos sonríen con tanta facilidad luego de esta tragedia?}

SB: Esto me lo pregunté mucho, y no lo escribí, porque no hay como escribir sobre la cultura de la gente sin parecer que uno los está criticando. Yo no vi llorar a los damnificados, no vi llorar a nadie, esto se conecta con la idea de la relación cotidiana con la muerte y la falta del duelo. Por ejemplo cuando alguien muere en Haití, lo primero que se hace es sacarlo de la casa y creo que esto es una mezcla de religiones, dónde evidentemente el vudú tiene algo que ver. El muerto se saca de la casa, se entierra rápido, la gente le tiene miedo al muerto, el duelo se vive de una forma muy diferente a otros 
países. Esto tiene efectos en la sociedad a largo plazo y a lo mejor es una de las razones de por qué había tantos muertos todavía en las calles, porque creo que era un poco el miedo de la gente de cubrirlos y tocarlos. Obviamente sin olvidar la dificultad que tendría cualquier ciudad en el mundo en enterrar 12.000 cadáveres. No creo que ninguna ciudad esté lista para hacer esto de un día para otro, pero obviamente esto se vuelve más grave en un país dónde la relación de los vivos y el miedo al muerto es muy profunda.

\section{En el momento de capturar las fotografías ¡en qué pensaba, en lo ético, moral o profesional?}

SB: Un poco en todo. Por un lado, tomaba fotos para acordarme de lo que estaba viendo, aún creo que no puedo olvidar muchas cosas, pero en mi cerebro pasaba algo como que al ver tantos muertos, además ya estaban inflados, deformados, no los registraba como humanos, entonces, no me conmovía viendo tantos muertos, sino que la conmoción venía luego cuándo hablando con los otros, con los vivos, pensaba que eran personas que estaban en una clase en la universidad. Me encontré con una monja colombiana que en frente a su casa había todavía cinco muertos tirados en el piso, estaban en un edificio del frente, murieron en una universidad que se había caído, eran jóvenes que estaban estudiando. Parecían imágenes de Pompeya, una ciudad cerca a Nápoles en Italia, donde luego de la erupción del volcán Vesubio los muertos quedaron como fósiles y en posiciones como pidiendo ayuda o intentando cubrirse de lo que les caía encima, y a mí, aquí en Haití, me daba la misma impresión, pero también, por la forma y por el olor.
Esto lo tuve que elaborar posteriormente.

En cambio, lo que sí era lo más impactante se veía en los hospitales, los niños heridos, esto era realmente inaguantable, muy duro y muy triste. Los verdaderos héroes del terremoto fueron los médicos que llegaron de todas partes del mundo, no dormían y no tenían donde hacerlo. Sus maletas estaban tiradas afuera de todos los hospitales, y en algunos hospitales dormían debajo de las camillas de los pacientes. Hubo incluso médicos que hicieron ochenta operaciones en ocho días, y seguían sonriéndole a los niños y ayudando a los pacientes con la mejor voluntad. Por ejemplo, los Médicos Sin Fronteras, los colombianos, me acuerdo mucho de una doctora Mara colombiana, que estaba en el hospital de la ONU de la Cruz Roja Colombiana. Creo que todos estos médicos son la nota positiva, pese a que tuvieron que trabajar en condiciones terribles. Por ejemplo, en el caso de fracturas se vio este drama humano, porque son muy complicadas de tratar, y allí no había los instrumentos, por eso tuvieron que hacerse tantas amputaciones.

Las fotos y los niños también me causaban muchos sentimientos encontrados, porque yo no quería tomarles fotos a los niños en los hospitales, pero como siempre suele suceder a ellos les encanta. Tomé unas cuantas y ellos sonreían, pero me imaginaba a mí mismo en la situación opuesta, es decir, estar en un hospital después de vivir todo lo que habían padecido, y pensaba que si alguien hubiese llegado con una cámara de fotos yo me hubiera puesto muy molesto, pero los haitianos no se molestaban por esto, por el contrario eran amables $\mathrm{y}$ te daban siempre una sonrisa, entonces
Las fotos y los niños también me causaban muchos sentimientos encontrados, porque yo no quería tomarles fotos a los niños en los hospitales, pero como siempre suele suceder a ellos les encanta. 
por esa aceptación de parte de ellos fue que seguí tomando fotos de los heridos, sino obviamente no lo hubiera hecho.

\section{¿En lo político y lo cultural qué considera que se debe hacer en Haití?}

SB: Políticamente hay que volver a empezar. Por un lado, se entiende que el gobierno ha sido decapitado por el terremoto, se derrumbaron el palacio presidencial y el parlamento. Además el gobierno estuvo totalmente ausente después de la catástrofe, el presiente René Preval era como una especie de fantasma. Nunca lo vimos ir a los campamentos a darle aliento a la gente, por el contrario, viajó a Santo Domingo y cuando se iba, nadie se daba cuenta porque era como un fantasma, que hablaba más con los medios internacionales que con los nacionales. Lo que habría que hacer es crear una nueva clase política seria, no sé qué tan fácil pueda ser, de pronto imposible y culturalmente utilizar lo que se ve como negativo en una forma positiva, ver la amabilidad y la capacidad de soportar tragedias para de allí empezar a construir un nuevo Haití.

\section{¿Este cubrimiento como le aportó en lo profesional?}

SB: Hacer este tipo de cubrimientos es una escuela, todo el día uno debe ingeniarse las formas de poder hacer el trabajo, hay que crear, escribir y dormir en el piso, no hay nada de tomar, de comer, no había luz, no había conexión a internet, eran condiciones difíciles de hacer el trabajo.

Pero en lo humano lo que me ha pasado es que al estar allá creía que estaba bien, pero al tomar la avioneta y llegar a Santo Domingo, cuando ya me encontré solo en el aeropuerto de esa ciudad, empecé a darme cuenta que las cosas en mi no estaban bien, no tenía ganas de hablar, me daban ganas de llorar y llegando a Colombia, pese a que normalmente no peleo con nadie, tuve una discusión con una persona del DAS y luego con otra de la DIAN, evidentemente no estaba bien.

Mi reacción fue volverme un poco intransigente, molesto e irritable, en los días siguientes la cosa fue mejorando poco a poco cada día, pero lo que viví y vi allí lo he ido procesando poco a poco, es algo que se va elaborando con el tiempo. Esto es lo que se conoce como el estrés postraumático, pero uno se pregunta, si esto me pasa a mi que estuve solo diez días, qué le sucede a los haitianos que están allá y continúan con su tragedia, aquí es dónde uno se da cuenta de la inmensa cantidad de ayuda que necesita la gente, no solo física, sino para superar como sociedad lo que han vivido.

\section{¿Cómo fue el papel de los medios de comunicación?}

SB: Hay periodistas que hicieron las cosas distintas e incluso se quedaron en Santo Domingo, y desde allí escribían sobre lo que no estaban viviendo, y reportaban muchos hechos de violencia en Haití, pero la mayoría de los periodistas que estaban en Puerto Príncipe hicieron un buen trabajo. No hubo censura para la prensa y muchos compartíamos los mismos puntos de vista de la situación vivida.

En cuanto al tema de las ayudas, hay que recordar que en Italia hubo hace poco un terremoto y se rescataron vivas de los escombros 130 personas, fue un terremoto pequeño, pero en Haití con toda la ayuda internacional, se rescataron apenas solo 130 personas, lo que nos permitiría concluir que los rescates no fueron tan bien organizados. 
¿Qué mensaje daría a los jóvenes universitarios del periodismo?

SB: A quienes se están formando en lo profesional en comunicación, les diría que se debe ir al lugar de los hechos, hay que meterse con la gente, comer lo que comen, ensuciarse con ellos, respirar lo que respiran, oler lo que huelen para después con- tarlo. Y, en la parte humana, lo más importante, es no acostumbrarse a esto, es decir, cuándo uno cubre varios hechos fuertes, hay que seguir emocionándose y no dejar que las cosas te pasen por encima y se vayan, hay que reflexionar y meterse en los pantalones de las personas de las cuales se va a contar la vida. 